\title{
This special volume of mesothelioma is dedicated to my friend Adi Gazdar
}

As of today, Adi has $>130,000$ citations and an H-index of 175. Adi was the "father" of what it is now known as molecular pathology. Trained as a classic pathologist at Harvard, he applied molecular biology to pathology and elucidated the genetic alterations of lung cancer. In other words, he revolutionized the world of pathology using molecular biology. He established many cell lines, one of them was the ONLY cell line in which retroviruses grew: it was used to discover first HTLV1, and later to isolate and grow HIV. Adi told me: without my cell line, NCI would have closed all retro-virology labs! I met him at a meeting where I presented my work showing that SV40 DNA was present in some human mesotheliomas. He told me: I do not believe your data, I will test your hypothesis in my lab and disprove your findings. Yes, he spoke his mind, very directly, I was scared, he was quite famous, I was just a "kid". He called me a few months later, he said remember me? Sure, Dr. Gazdar, so? So you were right! I laser microdissected mesothelioma and nearby normal tissue and found SV40 only in tumor cells. Since then we became friends!

A year ago, he told me he wanted that I edited an issue of TLCR dedicated to mesothelioma. He said he would have contributed the article about SV40 and mesothelioma and that he would have liked to have me and Janet Butel as co-authors of his article. When Adi asked something, it was very difficult to say no. A week later he sent me a power point outlining the article he planned to write, with the 2 figures included in the SV40-mesothelioma article, soon after he died, unexpectedly. I felt I owed to Adi to bring this issue of TLCR to light and I am thankful to all those who enthusiastically contributed an article to this issue. These articles have been written by the top experts in the field, all have gone through a rigorous peer review process. I hope this comprehensive issue will serve as a guide to mesothelioma to both MDs and $\mathrm{PhDs}$.

\section{Acknowledgments}

Funding: Dr. Carbone reports grant support from the National Institutes of Health (1R01CA198138; 1R01CA237235; 1R01ES030948), the US Department of Defense (CA150671P1), and from the University of Hawaii Foundation that received donations to support Dr. Carbone research on Mesothelioma from: Honeywell International Inc., Riviera United-4-a Cure, the Maurice and Joanna Sullivan Family Foundation and the Germaine Hope Brennan Foundation. .

\section{Footnote}

Provenance and Peer Review: This is an invited article commissioned by the Editorial Office, Translational Lung Cancer Research. Not externally peer reviewed.

Conflicts of Interest: MC serves as the unpaid Guest Editor of the focused issue "Mesothelioma: What We know and What We Do Not Know in 2020)". TLCR. Vol 9, Supplement 1 (February 2020). MC has a patent issued for BAP1. MC has a patent issued for "Using Anti-HMGB1 Monoclonal Antibody or other HMGB1 Antibodies as a Novel Mesothelioma Therapeutic Strategy," and a patent issued for "HMGB1 As a Biomarker for Asbestos Exposure and Mesothelioma Early Detection". MC is a board-certified pathologist who provides consultation for mesothelioma expertise and diagnosis, including paid medicallegal consulting.

Ethical Statement: The author is accountable for all aspects of the work in ensuring that questions related to the accuracy or integrity of any part of the work are appropriately investigated and resolved.

Open Access Statement: This is an Open Access article distributed in accordance with the Creative Commons AttributionNonCommercial-NoDerivs 4.0 International License (CC BY-NC-ND 4.0), which permits the non-commercial replication and distribution of the article with the strict proviso that no changes or edits are made and the original work is properly cited 
(including links to both the formal publication through the relevant DOI and the license). See: https://creativecommons.org/ licenses/by-nc-nd/4.0/.

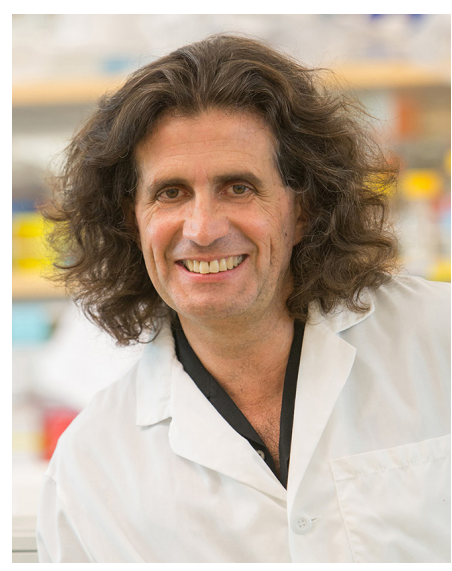

Michele Carbone

Michele Carbone, MD, PhD

William \& Ellen Melohn Chair in Cancer Biology; Director, Thoracic Oncology, University of Hawaii Cancer Center; Professor, Department of Pathology, Fobn A. Burns School of Medicine. Department of Pathology, University of Hawai'i Cancer Center,

Honolulu, HI, USA. (Email: mcarbone@cc.bawaii.edu)

Submitted Dec 30, 2019. Accepted for publication Jan 14, 2020.

doi: $10.21037 /$ tlcr.2020.01.15

View this article at: http://dx.doi.org/10.21037/tlcr.2020.01.15

Cite this article as: Carbone $M$. This special volume of mesothelioma is dedicated to my friend Adi Gazdar. Transl Lung Cancer Res 2020;9(Suppl 1):S1-S2. doi: 10.21037/ tlcr.2020.01.15 